\title{
Sangre y cuerpo. Arte, religión e individuo
}

\author{
Joaquín Francisco TORREGO GRAÑA ${ }^{1}$ \\ ftorrego@ya.com
}

Enviado: $12 / 03 / 2011$

Aceptado: 12/10/2011

\section{RESUMEN}

El artículo discurre sobre la presencia de ritos y rituales de sangre en sociedades humanas de muy distintos ámbitos geográficos y culturales desde tiempos primitivos.

Manifestaciones atávicas de profunda agresión y dolor físico que son relatadas por los mitos, las religiones y por supuesto el arte. Y que hoy siguen teniendo lugar, por alguna razón de lo humano, en la mente y la iconografía moderna conformadas en acciones ya explícitamente cruentas ya revestidas de incisiva asepsia, que suceden a diario.

Palabras clave: Carne, sangre, mito, religión, arte.

\section{Referencia normalizada}

TORREGO GRAÑA, J. F. (2011). "Sangre y cuerpo. Arte, religión e individuo". En Arteterapia: Papeles de arteterapia y educación artística para la inclusión social Vol.: 6. Páginas 237-251 Madrid. Servicios de publicaciones UCM.

\section{SUMARIO}

Rito: costumbre o ceremonia. Ritual: conjunto de ritos de una religión, de una iglesia o de una función sagrada. Cuerpo físico y arte actual. Referencias bibliográficas.

\section{Blood and body. Art, religion and individual}

\begin{abstract}
The article goes on the presence of blood rites and rituals in human societies from very different geographical and cultural rights since primitive times. Manifestations of deep atavistic aggression and physical pain are reported by the myths, religions and of course art. And still taking place today, for some reason the human, in the minds and actions shaped in modern iconography and explicitly bloody and covered with incisive asepsis, which happen daily.
\end{abstract}

Keywords: Flesh, blood, myth, religion,art

\section{CONTENTS}

Rite: custom or ceremony. Ritual: A set of rites of a religion, a church or a sacred function. Physical body and contemporary art. References. (CAM).

${ }^{1}$ Departamento Dibujo I, Facultad de Bellas Artes UCM. Escuela de Arte $\mathrm{N}^{\mathrm{o}} 10$ de Madrid 


\section{RITO: COSTUMBRE O CEREMONIA. RITUAL: CONJUNTO DE RITOS DE UNA RELIGIÓN, DE UNA IGLESIA O DE UNA FUNCIÓN SAGRADA}

Un rito, religioso o laico, es un acto de carácter ceremonial que ha de llevarse a cabo en lugares sacralizados y de acuerdo a unas normas estrictas determinadas por la tradición o por una autoridad, con la habitual presencia de un oficiante-mediador, chamán, sacerdote, artista...

Los ritos celebran la esencia del relato y del pensamiento mítico ancestral, de ahí su profundo carácter simbólico. Con sus extrañas reminiscencias que se pierden en el acervo de la cultura, los ritos han sido el medio individual o colectivo de comunión con fuerzas superiores. Como actos representacionales pautados en sus contenidos y en sus formas reiteradas, suponen la re-interpretación de dramas arquetípicos; por tanto son el origen de la Tragedia y de gran parte de la moderna acción performativa.

Hemos creado, mantenido, reelaborado, mitos y ritos para todos los gustos y según nuestras necesidades: fundacionales, conmemorativos, de consagración o legitimación en el poder; exocizantes, de purificación y expiación; ritos de iniciación, relativos a las estaciones y a los ciclos naturales; de transición hacia otros estadios generacionales o espirituales; oraculares, funerarios...

Es habitual que los ritos conlleven formas de sacrificio. Entre las acepciones señaladas por la Real Academia un sacrificio es un acto de abnegación, "una acción a que alguien se sujeta con gran repugnancia por consideraciones que a ello le mueven". Luego conlleva de algún modo una oblación u "ofrenda a una deidad en señal de homenaje o expiación".

En sociedades civilizadas y de carácter civilizador, el rito alcanza un sentido abstracto quedando en manifestaciones espirituales con el tiempo excesivamente neutras como las que hoy hallamos en nuestros cultos y modos occidentales ${ }^{2}$. Sin embargo en sociedades primitivas o no primitivas pero en determinados aspectos aún muy vinculadas a profundos sentimientos atávicos, la oblación fue y sigue siendo material (como la ofrenda de alimentos) y por supuesto física, carnal.

En la Antigüedad los sacrificios cruentos implicaban holocaustos y hecatombes de víctimas propiciatorias ya animales ya humanas. Estos son los llamados ritos y sacrificios "de sangre". La historia nos ha dejado numerosos ejemplos atestiguados a través de textos y representaciones artísticas (caso de las culturas precolombinas americanas, en especial de Mesoamérica).

De igual modo, por el estudio de las religiones comparadas y por la interpretación antropológica del mito poético, es de suponer que el sacrificio humano haya estado presente en los cultos prehelénicos del mediterráneo oriental dentro de los ritos vegetativos de las sociedades agrarias neolíticas y de los metales.

La sangre, el vino puro o rebajado y el aguamiel fueron alimento de dioses y de

${ }^{2}$ Véase CAMPBELL, J. "El mito y el mundo moderno", en CAMPBELL, J. en diálogo con MOYER, B. (1988). El poder del mito. Barcelona. Emecé Editores 1991, pp. 34-37. 
difuntos. En el relato grecolatino las libaciones de sangre derramadas en la tierra, sobre altares ctónicos y sobre túmulos funerarios tenían por objeto aplacar la ira de los dioses o establecer un vínculo entre vivos y muertos atrayendo sus espectros a la superficie desde el inframundo": "Hijo de Peleo, dice Neptolemo, recibe el brebaje grato a los muertos; ven y bebe de esta sangre." (Eurípides, Hécuba, 536).

Libaciones en particular dedicadas a los héroes difuntos que vagan sin sentido por los Campos de Asfódelos, primera región del Tártaro, con el único consuelo de ese alimento que les haría por momentos sentirse de nuevo "casi hombres".

Virgilio en su Eneida (Libro VI) describe el siguiente ritual infernal que ejecuta Eneas:

Aquí primero cuatro novillos de negro lomo dispone / y les riega la sacerdotisa de vino la frente, / y tomando de entre los cuernos las cerdas más altas/las arroja a la llama sagrada, ofrenda primera, / invocando a voces a Hécate poderosa en el cielo y el Érebo. / Otros hincan por debajo los cuchillos y la tibia sangre / recogen en páteras. El propio Eneas a una oveja de negro / vellón en honor de la madre de las Euménides y la gran hermana / la hiere con su espada, y para ti, Prosérpina, una vaca estéril; / luego prepara al rey estigio nocturnas aras / y pone sobre las llamas las entrañas enteras de los toros, / y derrama pingüe aceite sobre las vísceras ardientes. / Y de repente, bajo el umbral del sol primero y del orto / bajo sus plantas comenzó el suelo a mugir y las cimas de los bosques / a agitarse y se escuchó como un aullar de perras por la sombra / según se acercaba la diosa. "¡Lejos, quedaos lejos, profanos! / -exclama la vidente-, jalejaos del bosque entero!; / y tú emprende el camino y saca la espada de la vaina: / ahora, Eneas, valor precisas y ahora un ánimo firme". / Sólo esto dijo fuera de sí y se metió por la boca del antro.

Existía en estas tradiciones un tabú sobre los alimentos de color rojo que corresponden a los muertos. La granada es el fruto agridulce del Infierno, atributo de Core

\footnotetext{
${ }^{3}$ En Grecia las libaciones destinadas especialmente a las deidades subterráneas y a los difuntos fueron las llamadas choai del verbo chein, "derramar copiosamente" que refiere a un rito muy concreto en el que se arrojaba sin control la sangre, el vino o el aguamiel desde un recipiente amplio y en honor a aquellos. El alimento para los muertos no era ni mucho menos sólo sangre, vino o leche. Todavía en la época romana de Ovidio y Virgilio tal y como éstos nos cuentan, sobre las tumbas se dejaban además tortas, sal, frutas, y se sacrificaban animales cuya carne se abrasaba por completo para que ningún vivo la pudiera tocar, al tiempo que se pronunciaban determinadas fórmulas religiosas para invocar al muerto. Se abrían agujeros en la tierra para depositar en ellos los alimentos sólidos y así hacerlos accesibles al difunto. La prohibición de que un vivo tocara estos alimentos era tajante. El olvido de realizar tales sacrificios y ofrendas periódicos suponía la salida de los muertos de sus tumbas para bagar como espectros recriminando a los vivos su dejadez y reclamando su alimento. Traían todo tipo de desgracias que no cesaban hasta que no se retomaban los debidos sacrificios. Sobre estos temas véase COULANGES, F., de (1989). La ciudad antigua. México. Ed. Porrúa, pp. 5-14.
} 
como Perséfone ${ }^{4}$. Su corteza es de color amarillento rojizo, parece una piel apergaminada; el interior abierto es una pulpa cuajada de multitud de granos rojos entre tejidos membranosos que recuerda una herida profunda. Por ello representa la carne lacerada de Adonis-Tammuz: el cuerpo desmembrado de dioses o semidioses masculinos, paredros sacrificados en viejos misterios de vida, muerte y renovación donde Perséfone -"la que trae la vida y la muerte"- sería precisamente la cara núbil de una supuesta trinidad femenina ancestral.

En la mitología y en el teatro clásico perviven estos dramas. Un caso muy claro lo encontramos en Las Bacantes de Eurípedes donde se relata el crudelísimo sacrificio del joven rey de Tebas Penteo, en los frondosos bosques del monte Citerón y a manos de su propia madre Ágave enloquecida y liderando a las mujeres tebanas, todas ellas sumidas en un estado desenfrenado inducido por un Dioniso vengativo:

(1110) Ellas incontables manos aplicaron al tronco del abeto y lo desgajaron del suelo. Penteo que se sentaba en lo alto, cae desde la altura, derribado por tierra entre incontables gemidos. Porque comprendía que estaba cercano a su perdición. Su madre fue la primera en iniciar, como sacerdotisa, el sacrificio, y se echa encima de él. Penteo se arrancó la diadema del cabello para que le conociera y no lo matara la infeliz Ágave. Al mismo tiempo decía, acariciando su mejilla: “¡Soy yo, madre mía, yo, tu hijo! ¡Penteo, al que diste a luz en la morada de Equión!" / (1120) "¡Ten piedad de mí, madre, y no vayas a matar, por culpa de mis errores, a tu propio hijo!" Pero ella echaba espuma de la boca y revolvía sus pupilas en pleno desvarío, sin pensar lo que hay que pensar. Estaba poseída por Baco, y no atendía a Penteo. Cogiendo con sus dos manos el brazo izquierdo, y apoyando el pie en los costados del desgraciado, le desgarró y arrancó el hombro, no con su fuerza propia, sino porque el dios había dado destreza a sus manos. Luego Ino completaba el resto de la acción, desgarrando su carne, mientras se le echaba encima Autónoe y toda la turba de bacantes. / (1130) Había un griterío total; a la vez él, que gemía de dolor con todo lo que le quedaba de vida, y ellas con sus gritos de triunfo. Arrancaba una un brazo, otra un pie con su calzado de caza, mientras en el descuartizamiento quedaban al desnudo sus costillas. Y todas, con las manos teñidas de sangre, se pasaban una a otra como una pelota la carne de Penteo. Ha quedado esparcido su cuerpo; un trozo al pie de las peñas abruptas y otro entre el follaje denso de la enrama-

\footnotetext{
${ }^{4}$ Según la tradición del mito poético la hija de Zeus y Deméter, la doncella Core come durante su primera estancia en el Infierno, raptada por su tío Hades, una o siete semillas de granada (según los autores) que es el fruto de los muertos. Queda por ello ligada al inframundo y se convierte en Perséfone, de phero y phonos, "la que trae la detrucción"; Persefata, de ptersis y ephapto, "la que fija la destrucción"; y finalmente en el panteón romano, Proserpina, "la terrible". Entre los muchos autores clásicos sobre este mito puede consultarse a Apolodoro, El himno homérico a Deméter. Perséfone tiene similitudes claras con la japonesa Izanami quien también queda vinculada al Inframundo tras probar el alimento de los muertos.
} 
da del bosque. No será fácil de encontrar. Y su triste cabeza, que ha tomado su madre en las manos, después de hincarla en la punta de un tirso la lleva como si fuera la de un león salvaje, en medio del Citerón.

Similar fin tiene el triste héroe Orfeo despedazado a manos de las Ménades tracias del terrible Dioniso en el monte Pangeo (véase el libro X de Las Metamorfosis de Ovidio). La cabeza de Orfeo, como las de otros héroes sacrificados, adquiere con ello poderes proféticos razón por la que se preserva y venera. El mismo DionisoZagreo, patrón de la agricultura y del teatro en el panteón heleno (antes dios de oscuro origen), sufre el sacrificio cruel: en una versión del mito se le hace hijo de Zeus y de la infernal Perséfone; la celosa Hera manda a los Titanes que lo descuarticen siendo niño y devoren su cuerpo, lo que hacen con excepción del corazón que es salvado y a partir del cual, vuelto a renacer.

Una de las mejores representaciones de estos ritos que el arte -en este caso cinematográfico- haya podido recrear, aparece en la célebre Medea (1969) de P. P. Pasolini. La secuencia es de altas cualidades documentales y antropológicas, plásticas e interpretativas ${ }^{5}$.

Es obvia la relación de todo lo expuesto con el sacrificio de Cristo como oblación por la que se expían los pecados del mundo. Es llamado Cordero de Dios, reminiscencia de las primitivas ofrendas de animales, y el sacerdote ofrece la metáfora de su cuerpo desmembrado en forma de torta de pan y vino consumidos en un acto eucarístico colectivo. Una vez más pasión y muerte ritual ante el grupo, santificación de la víctima y expiación de la comunidad. El sufrimiento físico como medio de redención y promesa de renovación e inmortalidad.

Claro que no olvidemos que Cristo fue ejecutado y él mismo, o sus seguidores, hicieron de esa ejecución un sacrificio litúrgico. En el siglo I la crucifixión era un método muy extendido de pena capital ${ }^{6}$ lo que nos lleva a observar posibles vinculaciones entre este tipo de sacrificios rituales y ejecuciones públicas conectadas o no con la religión. Sin duda aún hoy y en contextos muy ritualizantes, la pena de muerte conserva aspectos de sacrificio humano. Por ejemplo la chari'a (ley musulmana) en su versión tradicional fija penas como la decapitación (delitos de sangre, apostasías), mutilaciones (robo), flagelación (delitos sexuales), lapidación (adulterio probado) o los recientes ahorcamientos por homosexualidad...

\footnotetext{
5 (27/09/2007) Pasolini, María Callas - Medea (1969) 02/12. En http://www.youtube.com/watch?v=PIBmo0QyWqI . Fecha de consulta: 14/09/2010.

Sobre los desmembramientos del cuerpo extraemos un comentario del crítico Guillermo Solana en su artículo “Antoni Tàpies. El cuerpo despedazado" (Revista El Cultural, 26-11-03):

Como comprendió Walter Benjamín, el desmembramiento era una operación al servicio de la producción semiótica: el cuerpo humano debía ser despedazado para que sus fragmentos se trocaran en signos claros, trasparentes. Así se entendería también la función del martirio en la pintura barroca.

${ }^{6}$ En el siglo VI Justiniano impuso la ejecución en la hoguera. Obviamente un estado cristiano que ya había reconocido la cruz como el símbolo de su fe no podía seguir utilizando ésta en la pena capital. La pena se aplicó a numerosos herejes.
} 
Y no olvidemos la figura del mártir ("testigo" en griego) tan prolífica en la espiritualidad y en el pensamiento cristiano. Un mártir muere por un ideal o por una fe. Se distingue del héroe en que es condenado por un perseguidor de esa fe o ideal, y muere defendiéndolos, preservándolos. Su sacrificio se convierte en un testimonio de sangre, por eso el mártir es testigo de su creencia y la razón de su veneración (San Cipriano de Cartago, él mismo ejecutado mártir en 258 d. C., recomendaba mucho a sus sacerdotes que documentaran con todo detalle la muerte de mártires para su posterior culto). Por los primeros escritos cristianos en torno a los santos y mártires sabemos que el proceso criminal romano comprendía las fases de arresto, comparición, interrogatorio, tortura, sentencia y suplicio, todo un esquema ritual o de pasión que constituye la estructura del relato literario típico sobre estos asuntos.

Los educados en ámbitos de tradición católica tenemos muy presentes las imágenes de mártires en especial desde la visión de la iconografía del Barroco postTrento: tremendas representaciones pictóricas y escultóricas de cuerpos descoyuntados y mutilados resueltas con fuerte naturalismo (pensemos en los pasos procesionales) para despertar el temor y la devoción de los fieles.

Hay otros mártires que no proceden del entorno católico y cuya devoción nos es ajena aunque desgraciadamente los tengamos muy presentes: los terroristas suicidas que según bajo qué circunstancias se convierten en mártires. Este es un asunto en extremo candente que forma parte de los conflictos abiertos entre Occidente y Oriente Próximo. El Islam condena rotundamente los delitos de sangre, por supuesto el terrorismo, y el suicidio está estrictamente prohibido. Sin embargo en el ámbito del extremismo radical existe lo que los expertos llaman un jus in bello por el que el heroísmo bélico y el martirio están permitidos en épocas de conflicto armado permanente y activo entre los musulmanes y sus enemigos. Se trata de conductas violentas de autoaniquilación en el marco de la ley de la yihad militar y consideradas, por tanto, operaciones heroicas de martirio que nada tienen que ver con el suicidio. En opinión de algunos expertos como Bernard Freamon ${ }^{7}$ tales ataques o sacrificios según se miren, responden a reinterpretaciones chiitas del martirio de Hussein, nieto del profeta, ocurrido en el año 681 d. C. en el desierto de Karbala (Irak), y como auto-sacrificios extremos revivirían su ejemplo.

Un aspecto más a tratar es el de las mutilaciones de partes del cuerpo que en los rituales primitivos suele referirse a apéndices y en particular a los órganos sexuales. La propia circuncisión masculina podría entenderse como una forma de sacrificio. La amputación del pene o de parte del pene está presente en tribus indígenas como por ejemplo en Fidji donde se practica la subincisión de la uretra masculina.

En el caso de la mutilación genital femenina, la ablación tan tristemente aún extendida, sus razones sólo pueden hallarse en la incultura y el sometimiento masculino. Aún así quienes la imponen aducen argumentos a favor como la identidad cultu-

\footnotetext{
${ }^{7}$ Véase BERNARD K. F. (2003). Martyrdom, suicide, and the Islamic law of war: a short legal history. Fordham International Law Journal, vol. 27, p. 299. La Semana Santa islámica conmemora los luctuosos acontecimientos de Ashura (día diez del primer mes islámico llamado Muharram), el genocidio de la familia del Profeta y en particular el martirio de Hussein.
} 
ral, la respetabilidad y pureza de la mujer, higiene, fertilidad, prevención contra la promiscuidad, etc. Maire-Guy Bah Kone, famosa ejecutora de ablaciones de Costa de Marfil y en la ancianidad defensora de su abolición, considera necesario poner fin de manera radical a esta práctica que señala como "ritual" pero curiosamente advierte de la necesidad de que las administraciones financien "otros rituales de fuerte arraigo popular que requieren el sacrificio de animales" para aplacar la cólera de fuerzas ocultas .

También debemos mencionar la lesión no ya del cuerpo del otro sino del propio cuerpo. En la misma línea de lo tratado, la automutilación es un acto que busca alterar el estado de conciencia a través del daño físico por uno mismo infringido como manera de oblación, expiación o demostración de que en dicho estado se supera el dolor, se ha sublimado la carne y se ha alcanzado la plena comunicación espiritual con una supuesta deidad o fuerza superior. Se trata de un medio-modo de "iluminación espiritual a través de un ritual".

En el mito poético tenemos uno de los casos de expiación más célebres: Edipo quien se perfora los ojos con los alfileres del vestido de su madre al ser consciente del parricidio y del incesto que ha cometido (Sófocles, Edipo Rey). Charles Blondel (1906) propuso el término "edipismo" para las autolesiones oculares causadas por trastornos mentales.

Las automutilaciones aparecen en otros universos mitológicos como son el complejísimo mito japonés o el mesoamericano. Según Furst ${ }^{10}$ entre las costumbres mayas y del México central, la automutilación está extensamente documentada en el arte ritual al menos desde 1. 300 a. C. hasta la época colombina, "incluyendo la perforación del pene, de la lengua y de otros órganos con espina de cacto, púas de pastinaca y otros instrumentos punzantes". Es obvio que el tremendo dolor físico de estos cruentos ritos sólo podían ser soportados con la ingesta de sustancias psicoactivas además de rezos y sonidos repetitivos que estimulasen las mencionadas alteraciones profundas de conciencia.

Cabe referirnos, por último, a los llamados estigmas: heridas abiertas parecidas a las que según la iconografía cristiana habría sufrido Jesús en su crucifixión. Aparecen en la carne de devotos de manera recurrente y tienen larga presencia en la espiritualidad popular.

El primer caso célebre y constatado fue el de la Beata María de Oignies (c. 1177-1213) aunque en general este honor se le atribuye a San Francisco de Asís. ¿Se trata de mutilaciones de origen sobrenatural que vienen a señalar al afectado, o de automutilaciones físicas o psicosomáticas? En cualquier caso son laceraciones

${ }^{8}$ (06/08/2002) LÓPEZ DUSIL, Ricardo. Circuncisión femenina: un ritual que mutila a dos millones de niñas cada año. En www.elcorresponsal.com. http://www.webislam.com/?idt=1118. Fecha de consulta: 15/09/2010.

9 AutoLesión: Información y Apoyo A.C., Para entender la autolesión. En http://www.autolesion.com/services.asp? service=12, fecha de consulta: 15/09/2010.

${ }^{10}$ Véase FURST, P. T. (1980). Los alucinógenos y la cultura. México. Ed. Fondo de Cultura Económica, pp. 32-33. 
muy representadas a lo largo de la historia que hoy siguen despertando devociones y aportando repertorios de imágenes y acciones de muy diversa interpretación, además de puramente artísticas.

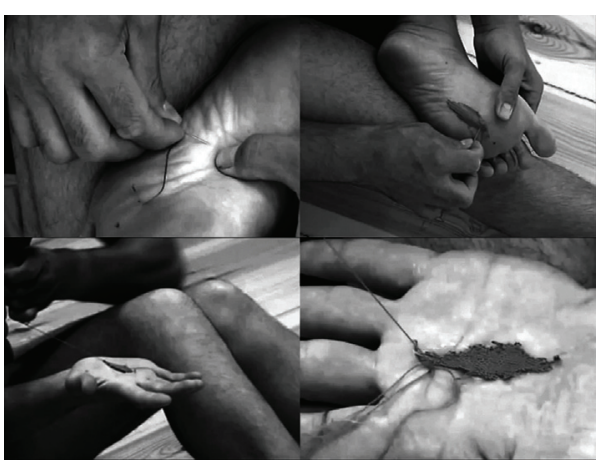

Fig. 1. Cosidos con hilo rojo en la planta de las manos y de los pies. Joao Pereira, 2003

\section{CUERPO FÍSICO Y ARTE ACTUAL}

El dolor, la carne y el sacrificio del cuerpo han sido tratados con profusión a lo largo de la historia: lo encontramos en las ya mencionadas representaciones de la pasión y crucifixión de Cristo y de aquellos innumerables mártires católicos; en el ámbito protestante-calvinista, con su óptica laica del asunto, en las célebres Lecciones de anatomía o en el Buey desollado de Rembrandt. Rosa Montero escribió en un artículo titulado La Carne (Revista de El País, 5-05-2002): "son siglos y siglos de actuaciones sobre la carne, sobre el cuerpo, intentos milenarios de poseer, controlar, castigar, reconducir, reinventar, nuestra materia".

El siglo XX devolvió el cuerpo y sus gestos más atávicos a la escena artística: desde la idea romántica que hereda el expresionismo abstracto del artista épico comportándose como héroe mítico a la búsqueda de una supuesta verdad ancestral (Pollock, Rothko) a la figura del artista-sacerdote, gurú poseedor de esa verdad (Beuys), o a los accionistas con sus actos entre plástica moderna y rito primitivo.

Debemos no obstante advertir que en el terreno artístico contemporáneo las agresiones infringidas o auto-infringidas en el cuerpo del artista, si bien a veces han sido reales -Gina Pane en la famosa Escalada Sin Anestesia o Chris Burden crucificado sobre un Volkswagen en 1974- muchas otras han sido aparentes o se basaron en la idea de herida psicológica o social.

Cuatro de las personalidades artísticas que bien ilustran este punto son los accionistas vieneses. Señalamos en especial a Nitsch quien ya en 1962 iniciaría una serie de acciones que él llamó "ebrio éxtasis de la vida" (Orgía-Misterio-Teatro). Con sus colaboradores arrastraba un animal sacrificado y abierto en canal delante del público, luego cubría con las vísceras y la sangre arrojada a cubos el cuerpo de un sujeto, a menudo varón, desnudo y crucificado. Aunque quizás el más radical del cuarteto fuera Schwartzkogler con acciones llenas de violencia y pornografía simbólica. Al final de su vida, citó a la crítica para una performance en la que los invi- 
tados veían a través de una pantalla cómo él mismo se amputaba su pene en otra habitación ${ }^{11}$.

El arte de finales de los ' 80 incrementó este interés por el cuerpo plasmado desde todos los ámbitos visuales y plásticos posibles y de una manera muy insistente. Entre las diversas razones que se aducen para ello suele destacarse la irrupción del sida.

Dicho interés ya había comenzado -como hemos apuntado- a principios de los '70, incluso antes, y llegará hasta finales de los '90 de una manera creciente. A lo largo de esas décadas la actitud del artista hacia el cuerpo, el propio, el ajeno, el individual y el colectivo, se va a ir desplazando desde lo identitario y reivindicativo a lo mórbido, lo despiadado, lo grotesco, lo deforme. La carne mutilada y la automutilación. Pensemos en David Nebreda.

Se dio un desmedido afán por la transgresión sexual y pornográfica, el sadomasoquismo, la homosexualidad; por la escatología y lo fisiológico. Demasiado exhibicionismo y realismo sucio, demasiada trash culture.

Y se hace presente la difícilmente digerible obsesión del primer mundo por el cuerpo, cuerpos sanos y transgénicos, modelados, construidos y reconstruidos a golpe de bisturí (el carnal art de Orlan). Otra de las acepciones que introduce la Real Academia para el término sacrificio es "operación quirúrgica muy cruenta y peligrosa".

Paul MacCarthy, con su marcado gusto por las actuaciones obscenas, simula amputarse los dedos, pinta con su pene o con un pincel que es como una prótesis que lo agranda. Andrés Serrano sorprende en 1987 con su Cristo en Orina y en 1992 con su serie The Morgue. Nos cautivan y repugnan los retratos de vísceras de Helen Chadwick, y las terribles pero al tiempo bellísimas composiciones clasicistas de Witkin con su universo de seres monstruosos. Triunfan los muchachos irreverentes de Saatchi, Dinos y Jake Chapman (no olvidemos sus homenajes a Los desastres de la Guerra de Goya). Mike Kelly, Pettibon, Barney, Sherman...

\footnotetext{
${ }^{11}$ A partir de este hecho se extendió el rumor de que murió pocos días después por la gravedad de sus heridas; sin embargo uno de los asistentes, David Ross - director del Museo de Arte de San Francisco- confesó al crítico Haden-Guest que todo fue un montaje hecho con arcilla y que su autor realmente se suicidó al parecer por estar gravemente enfermo. (véase HADEN-GUEST, A. (1996). Al natural. La verdadera historia del mundo del arte. Barcelona. Ed. Península Atalaya, 2. 000, pág. 48).
} 


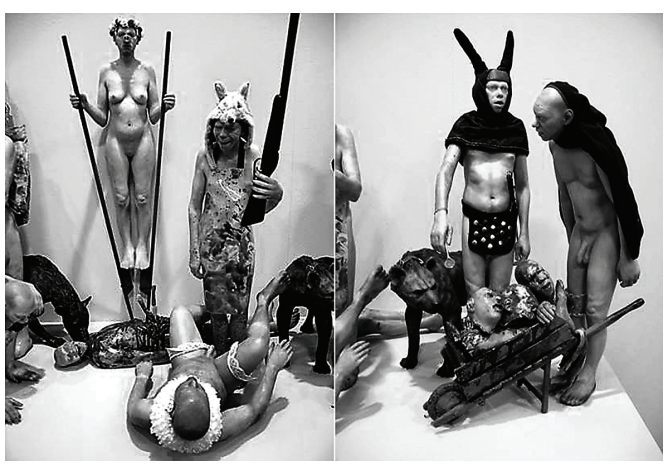

Fig. 2. Richard Stipl, I smell like I sound (2006). Christopher Cutts Gallery, ARCO 06
En nuestro país es obligado destacar la larga aportación al teatro performativo de la Fura dels Baus con montajes en los que el cuerpo y el cruento ritual atávico se han convertido en señas de identidad. Dentro del Manifiesto Binario el grupo escribe $^{12}$ :

En el Teatro Digital conviven la abstracción absoluta con el retorno al cuerpo, que puede adquirir una dimensión sadomasoquista, sensual, angélica o bien orgiástica, o quizás una mezcla de todas ellas.

Cada día asistimos a un corolario de impresiones visuales del dolor a través de la prensa gráfica, la televisión o Internet (imágenes de guerra, crímenes atroces, catástrofes naturales, rituales vigentes en otras culturas y religiones...); y de la mano de artistas plásticos en un modernísimo papel de testigos y voces de realidades sociales marginales.

Esta ha sido una postura muy extendida (ya saturante) entre creadores emergentes de finales de los '90 y en particular de los primeros 2.000: el artista que actúa como antropólogo, etnógrafo o reportero gráfico y que con un planteamiento en su obra de proyecto pseudo-científico y público, se lanza a documentar (testimoniar) desde su óptica no objetiva, situaciones diversas, conflictos sociales, incluso rituales como los aquí vistos.

Un clásico es Lothar Baumgarten (Rheinsberg, 1944). Siguiendo los pasos siempre como artista- de su padre eminente antropólogo, se ha venido interesando por las estructuras culturales, los rituales y los simbolismos de pueblos como los Yanomami. Su objetivo artístico no es la denuncia de la marginación de tales pueblos sino el replanteamiento de nuestras convenciones perceptivas, la creación de un discurso paralelo con materiales de origen primitivo, y la documentación de propias experiencias de tránsito mágico.

Otro clásico, sin duda merecedora de los títulos de reportera, artista y antropóloga, es Cristina García Rodero. Ahí está su dilatada carrera. Recordamos su exposición en la Sala Alcalá 31 de Madrid dentro de PhotoEspaña 2008: cerca de cien imágenes pertenecientes a un proyecto comenzado hace más de diez años en la montaña de Sorte (Yaracuy, Venezuela) donde se encuentra un complejo religioso espiritista dedicado a un personaje mítico llamado María Lionza. Rodero visitó por primera vez el lugar en agosto de 1998. Los rituales que allí vio y vivió, de orígenes incluso precolombinos, le hicieron plantearse asuntos tan importantes como el po-

\footnotetext{
${ }^{12}$ Fura dels Baus, Manifiesto Binario. En http://www.lafura.com/entrada/esp/manifest.htm. Fecha de consulta: 19/09/2010.
} 
der de la fe, la espiritualidad más primitiva en el ser humano, e incluso la tecnología de su propia cámara: dejó el analógico por un momento y se pasó al digital y al color para poder registrar, por ejemplo, la potencia de ciertos ritos nocturnos.

En la edición de 2010 del mismo festival hemos visto la exposición El amor y el éxtasis de otra gran fotógrafa, Isabel Muñoz. Maestra minuciosa y rigurosísima en las técnicas de procesado y revelado, es una infatigable exploradora del cuerpo humano contemporáneo expuesto en territorios de lo místico y lo extático. Destacamos de este trabajo las imágenes de miembros de la cofradía islámica Al Qadiriya quienes durante determinados ritos colectivos alcanzan estados de trance por la oración que les llevan a proferirse las más brutales auto-mutilaciones que uno pueda imaginar, sin percepción alguna de dolor. Ellos mismos se introducen largos clavos en sus cráneos a golpe de martillo, tragan cuchillas de afeitar y cristales, se perforan los párpados, la lengua, los costados, las palmas de las manos, con afiladas dagas

Isabel Muñoz ha sido testigo directo de tales rituales crudelísimos; los ha podido documentar en vídeo y fotografiar, a menudo con encuadres y tratamientos de luz y color que nos remiten a las representaciones clásicas del martirio y la pasión de santos y cristos. Una vez más se trata de la celebración y exaltación del sacrificio en una superación mística de lo físico. ¿Es necesario este dolor y desgarro de la carne para alcanzar la

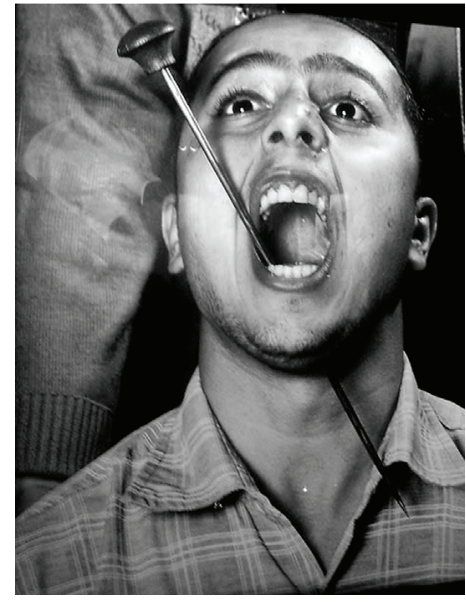

Fig. 3.

Isabel Muñoz, imagen de la exposición El amor y el éxtasis, Canal de Isabel II, Madrid visión de lo trascendente? Por lo ocurrido durante milenios y en muy distintas culturas y credos, parece que sí.

También dentro de PhotoEspaña 2010 se celebró en la Galería Gao Magee de Madrid, una exposición del prestigioso fotógrafo chino Han Lei. Retratos, bodegones y paisajes de corte pictorialista en los que el artista recurre tanto a las estéticas tradicionales de su país (desde la colorista Ópera China a los uniformes de Mao) como al clasicismo occidental con toques kitsch. Destacaremos lo más cruento y sin duda perturbador: la serie de retratos fotográficos Trece formas civiles ficticias de castigo. Han Lei retrata aquí a los personajes procesionales que, encarnando las trece terrible formas de castigo físico, desfilan en ciertos municipios del sur de China durante las celebraciones de Año Nuevo ${ }^{13}$ como rito festivo de expiación y ale-

13 Por ejemplo la famosa Hangzhou en la costa sudoriental china y capital del imperio en tiempos de la dinastía de Song cuando trascurre el drama de la novela citada (durante los años 1111-27). El 
jamiento del mal. La procesión hace alusión al drama de la famosa novela china Jin Ping Mei o El ciruelo en el vaso de oro (de autor desconocido, escrita entre finales del siglo XVI y principios del XVII). Considerada pornográfica e intermitentemente prohibida, narra en un episodio clave la relación adúltera entre Pan Jinlian (personaje femenino cuyo nombre simboliza la sinvergüenza en China) y Ximen Qing, corrupto comerciante lujurioso. La disipada Pan Jinlian asesina a su esposo para convertirse en la quinta esposa de Ximen Qing, su cómplice. La historia se centra en las relaciones de poder y sexo entre sus protagonistas en un ambiente social y político generalizado de injusticias, torturas, asesinatos y suicidios

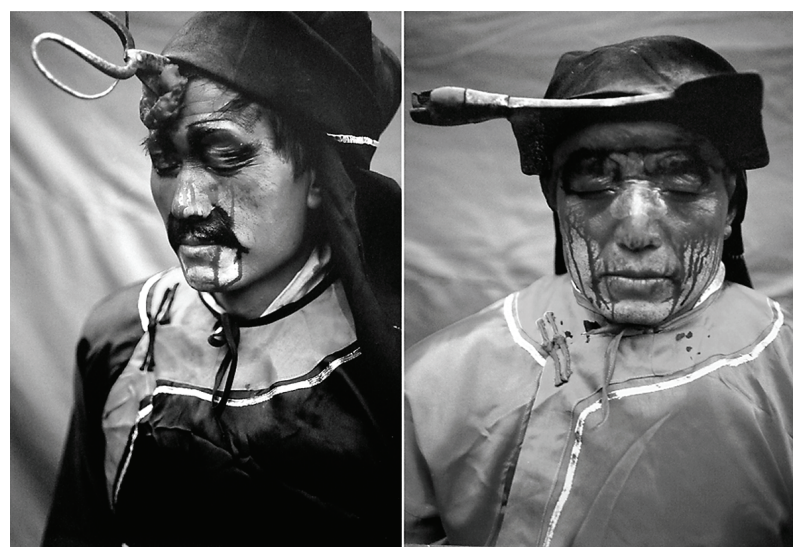

Fig. 4, Han Lei, fragmentos de la obra Trece formas civiles ficticias de castigo

Hasta aquí lo expuesto amen de una profusión actual de frikismo sobre el tema en imágenes reales o no (esto ya da igual) extendidas a través de las redes sociales. Quién no ha visto el traje de solomillos crudos que vistió recientemente la tal Gaga como nueva versión estilística y superficial de la vieja Perséfone núbil -recordemos la obra plástica de J. Sterback Vanitas: vestido de carne para un albino anoréxico (1987).

¿Hay en la representación y visión de la carne y del dolor algo estéticamente bello? Quizás sí, porque conmueva su contemplación o porque despierte nuestras pulsiones más primitivas. O ambas cosas a la vez. Quizás de ahí la atracción visceral al tiempo que la repulsión cultural y moral que nos suscita. En cierta ocasión un destacado fotógrafo especializado en moda me dijo "es fácil fotografiar el dolor"; y en ello razonaba su decisión consciente de dedicarse profesionalmente a plasmar la belleza en un medio tan aparentemente banal como la moda. Para él resultaba más ético.

octavo día del duodécimo mes lunar se consagra a los "sacrificios de invierno" con actividades festivas que expresan la cultura y las costumbres milenarias del país; durante la primera quincena del primer mes del año, las romerías se suceden. El personaje de Pan Jinlian, cuyas culpas sólo pueden ser expiadas con el justo castigo público, es popularmente bien conocido 
Nuestra sociedad es aséptica en la mayor parte de sus rituales establecidos. Sin embargo necesitamos mantener o recurrir a momentos de visceralidad que nos conecten con nuestros atavismos. Necesitamos contemplar dosis de ese dolor sangriento que ahora se halla en formas a menudo sofisticadísimas pero en definitiva cruentas por muy quirúrgicas que parezcan (la asepsia es aún más retorcida). Lo reprobamos, lo rechazamos y nos atrae.

Excepto en casos de patologías declaradas, asistimos con las manos entrevelando la vista al espectáculo ficticio del dolor y de la laceración del cuerpo -el éxito del cine gore. Vivimos las secuencias "reales" emitidas por la televisión o la red desde la distancia otra vez aséptica que interpone la pantalla del monitor. Las texturas que sobre las imágenes arrojan los medios de reproducción y emisión (tramados, pixelazos, luces irreales, colores ficticios, en definitiva ruido) actúan como filtros en nuestra experiencia del suceso.

¿Persiste el snobismo en lo obsceno que busca el escándalo y la provocación fácil como aquel arte de los '90? ¿O realmente existe una mística y una belleza objetivables en el dolor y en el sufrimiento? La respuesta está en cómo se trate visualmente el tema y hasta dónde se profundice emocional y conceptualmente en él como creadores y como espectadores. El dolor visto, representado, puede resultar tremendamente bello, conmovedor sin duda. No tiene por qué ser obsceno ni grotesco ¿O sí debe serlo según qué discursos y circunstancias? Tal vez lo obsceno y grotesco sea el hecho mismo de representarlo. Aunque probablemente sea necesario hacerlo, incluso natural no sólo cultural... Desde luego el arte nos ha dejado imágenes del dolor sublimes.

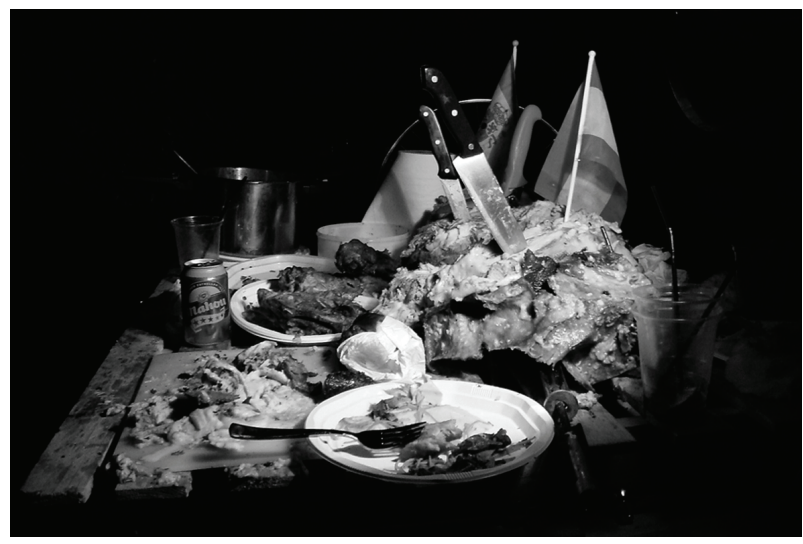

Fig. 5, Eva M. Lillo, Bodegón Tenebrista (2010), celebrando el último Mundial de Futbol

Los romanos, que en 97 a. C. suprimieron por decreto senatorial los sacrificios humanos ya entonces simbólicos, necesitaron los espectáculos de gladiadores como parte fundamental de su ocio civilizado-civilizador y de sus políticas de control. El 
estado cristiano los sustituyó por las carreras de caballos en el hipódromo de Constantinopla cuyo fanatismo entre facciones llegó a su punto álgido en los sucesos sangrientos de Nika (532 d. C.). De aquello a la violencia en el deporte actual; hasta las torturas de Abu Ghraib o a la ejecución de Saddam vistas una y otra vez en Youtube.

Marguerite Duras escribió (La Douleur, 1985) "el dolor es tan grande, se asfixia, no tiene aire. El dolor necesita espacio". 


\section{REFERENCIAS BIBLIOGRÁFICAS}

CAMPBELL, J. en diálogo con MOYER, B. (1988). El poder del mito. Barcelona. Emecé Editores.

CHECA, F. y MOLINA, P. (1997). La función simbólica de los ritos: Rituales y simbolismo en el Mediterráneo. Barcelona. Ed. Icaria.

OTTO, W. F. (1960). Dioniso, mito y culto. Madrid. Ediciones Siruela.

SALABERT, P. (2004). La redención de la carne: Hastio del alma y elogio de la pudrición, Murcia, Fund. Autisme Mas Casadevall, F. P.

SEGALEN, M. (2005) Ritos y rituales contemporáneos, Madrid, Alianza editorial. 